\title{
A study of sequential histopathology of Trypanoplasma borreli (Protozoa: Kinetoplastida) in susceptible common carp Cyprinus carpio
}

\author{
Sumrarn Bunnajirakul ${ }^{1, *}$, Dieter Steinhagen ${ }^{1, * *}$, Udo Hetzel $^{2}$, Wolfgang Körting ${ }^{1}$, \\ Wolfgang Drommer ${ }^{2}$
}

'Fish Disease Resarch Unit and ${ }^{2}$ Pathology Department, School of Veterinary Medicine, Bünteweg 17, 30559 Hannover, Germany

\begin{abstract}
The tissue response of common carp Cyprinus carpio to the kinetoplastid blood parasite Trypanoplasma borreli Laveran \& Mesnil, 1901 was investigated during a laboratory infection of a highly susceptible carp line. With the development of the parasitaemia an increased proliferation of the lymphoid renal interstitial tissue was induced, which resulted in a progressive depression and deterioration of renal tubules. In heavily infected carp at Days 20 to 28 post inoculation (PI), a tubulonephrosis, a glomerulitis caused by a massive accumulation of leukocytes in glomerular capillaries, and large numbers of trypanoplasms in blood vessels and renal interstitium were observed. Corresponding with rising $T$ borreli numbers in the penpheral blood, splenuc lymphocytes showed increasing proliferation rates, and the capillaries of the liver, gills, heart and intestine were infiltrated with lymphocytes and trypanoplasms. In heavily infected carp, congestion of liver sinusoids, focal necroses of hepatic tissue, extensive accumulations of erythrocytes in the spleen and in the blood marked anaemia were observed. These carp often showed abdominal distension, exophthalmus and swimming disorders described as 'sleeping sickness of carp' Proliferation of cells from the interstitial lymphoid tissue of the kidney, which bears a close resemblance to the bone marrow of higher vertebrates, is considered a normal immune response of fish to antigen challenge. We here describe the unique case of a severe but ineffective immune reaction which results in the destruction of excretory renal structures. This has to be considered a severe disturbance of osmoregulation in affected carp, which, together with a decrease in oxygen uptake due to anaemia, is likely a major cause of death in these carp.
\end{abstract}

KEY WORDS: Trypanoplasma borreli Cyprinus carpio Nephritis - Histopathology

\section{INTRODUCTION}

Trypanoplasma borreli is a flagellate blood parasite of European cyprinids (Lom 1979, Lom \& Dykova 1992). The infection is widespread in hatchery populations of common carp Cyprinus carpio, tench Tinca tinca, and goldfish Carassius auratus. It may also infect feral cyprinids such as rudd Scardinius erythrophthalmus, Leuscicus idus, Phoxinus phoxinus, and Rutilus rutilus (Kruse et al. 1989, Lom \& Dykova 1992). The cells of $T$. borreli are biflagellate, possess a short anterior free

- Present address: Faculty of Veterinary Medicine, Mahanakorn University of Technology, Bangkok, Thailand

-Corresponding author. E-mail: dstein@fisch.tiho-hannover.de flagellum and a long recurrent flagellum which is attached to the cell surface and forms an undulating membrane. A large elongated densely staining kinetoplast extends from the apex of the cell, and opposite to the kinetoplast lies a rounded nucleus (Kruse et al. 1989, Lom \& Dykova 1992). Trypanoplasms differ from the ectoparasitic forms from the closely related genus Cryptobia mainly in being transmitted by a leech vector, Piscicola geometra or Hemiclepsis marginata (Keysselitz 1906, Kruse et al. 1988). When ingested by a vector, $T$. borreli undergoes a series of divisions in the crop of the leech, but it remains infective to fish during the whole process of development. The presence of infective $T$. borreli in the vector was found to be terminated with the complete digestion of the blood 
meal. The longest infection period in the leech varied between 11 and 14 d (Robertson 1912, Lom 1979, Kruse et al. 1989)

In the laboratory an infection can be induced by injection of infected blood into the muscle or the body cavity of recipient carp (Lom 1979, Steinhagen et al. 1989). At $20^{\circ} \mathrm{C}$ flagellates were present in the circulating blood about $1 \mathrm{wk}$ post inoculation (PI) into the muscle of a carp. Then the parasite number increased and peaked 3 to $4 \mathrm{wk}$ PI. In the following chronic phase of infection fluctuating numbers of Trypanoplasma borreli were counted. This was followed by a phase of decreasing numbers of blood parasites. At about 4 mo PI, no $T$. borreli were found in the circulating blood (Steinhagen et al. 1989).

In some strains of carp and goldfish Trypanoplasma borreli may multiply to a high parasitaemia which may cause disease conditions and mortality (Dykova \& Lom 1979, Wiegertjes et al. 1995). In goldfish, trypanoplasmosis was associated with anaemia, splenomegaly and ascites causing abdominal distension (Lom \& Dykova 1992). In heavily infected fish, lesions were found in most body organs, with intracapillary glomerulitis and tubulonephrosis in the kidney, focal necrosis in the liver, and activated spleen pulp with increased lymphocytic infiltration (Dykova \& Lom 1979).

Because Trypanoplasma borreli is easy to maintain in the laboratory by syringe passage, several strains (Lom 1979, Lom \& Dykova 1992) were raised and used in studies on the biology and phylogeny of kinetoplastids (Lom. 1979, Wiemer et al. 1995, Lukes et al. 1997). A cloned strain of $T$ borreli was established and characterized by Steinhagen et al. (1989) and used as a laboratory model in the study of antibody levels in outbred carp and the genetic basis of disease resistance in fish (Jones et al. 1993, Wiegertjes et al. 1995). These studies indicated that the cloned strain of $T$. borreli rapidly multiplied in carp from a highly susceptible inbred fish line and caused severe mortality (Wiegertjes et al. 1995). To analyse the pathology associated. with this infection model, the present study was undertaken. We used isogenic hybrid $F_{1}$ carp from the susceptible fish line and a definitive inoculum of cloned $T$. borreli (5000 parasite cells) to examine the sequential histopathology associated with increasing parasitaemia in the blood of infected carp.

\section{MATERIALS AND METHODS}

Fish. Carp from a single crossing $($ E20 $\times$ R8, Wageningen Agricultural University) were used in the study throughout. The female (E20) originated from an isogenic gynogenetically reproduced outbred female, which was crossed with a male of Hungarian origin
(Wiegertjes et al. 1995). The carp were produced and raised under parasite-free conditions in filtered recirculating tap water at $20 \pm 2^{\circ} \mathrm{C}$. After initial feeding of Artemia salina, the feeding regime was switched to commercial carp chow (Alma, Kempten, Germany) at a ratio of $2 \%$ of the body weight daily. The carp were used in the experiments at an age of 4 to 7 mo and a weight of 30 to $50 \mathrm{~g}$.

Parasite infection and histopathology. Trypanoplasma borreli was cloned and characterized previously (Steinhagen et al. 1989), and was maintained in the laboratory by syringe passage through highly susceptible carp. For the experiments of the current study, 18 carp were infected by injection of $5000 \mathrm{~T}$. borreli into the dorsal muscle and kept at $20 \pm 2^{\circ} \mathrm{C}$. At $7,14,18,19$, and $21 \mathrm{~d}$ PI, 3 carp were anaesthetized with tricaine $(0.15 \mathrm{~g}$ $\left.\mathrm{l}^{-1}\right)$, chilled on ice, exsanguinated, and necropsied. Samples from gills, spleen, liver, kidney, intestine, heart and brain were taken immediately, fixed with phosphate buffered formalin ( $4 \% \mathrm{v} / \mathrm{v}, \mathrm{pH} 7.2$ ), dehydrated in a series of graded ethanols and embedded in glycol methacrylate (Technovit 7100, Heraeus-Kulzer, Germany). From the blocks, 3- $\mu$ m thick sections were cut, stained with Giemsa's (Romeis 1989) and observed with a Zeiss photomicroscope (Zeiss, Oberkochem, Germany). Additionally, blood samples were taken for determination of parasitaemia and haematocrit. As controls, 18 uninfected carp from the same stock were kept together with the infected fish. For histology, 3 carp were sampled at 7, 18, and $21 \mathrm{~d}$ PI and processed correspondingly. The remaining carp were processed for haematology and microbiology only.

Determination of cell proliferation rates. To analyse the impact of a Trypanoplasma borreli infection on the proliferation of cells in different organs, 18 carp of about $10 \mathrm{~g}$ were infected with $5000 \mathrm{~T}$. borreli, and 18 uninfected carp from the same stock were used as controls. At $7,14,18,20,24$, and $28 \mathrm{~d}$ PI, 3 infected and 3 uninfected carp were injected with 5-bromo-2-deoxyuridine (BRDU, Sigma, St. Louis, MO, USA) solution at a dosage of $250 \mathrm{mg} \mathrm{kg}^{-1}$ body weight $5 \mathrm{~h}$ before tissue sampling. The carp were subsequently killed and necropsied. Samples from spleen, liver, and kidney were taken and embedded in paraffin wax. From the blocks $4-\mu \mathrm{m}$ thick tissue sections were cut, deparaffinized and rehydrated. Incorporated BRDU was detected by indirect immunoperoxidase staining according to standard procedures (Schutte et al. 1987) adjusted to the carp system (Hemmer \& Steinhagen 1995). Incorporated BRDU was labelled by successively incubating the sections in anti-BRDU monoclonal antibody (diluted 1.50 in Tris-buffered $0.5 \mathrm{M}$ phosphate buffered saline, PBS, 1 h at 20 to $24^{\circ} \mathrm{C}$ ), biotinylated rabbit anti-mouse antibodies (1:50 in the same buffer, 1 h at 20 to $24^{\circ} \mathrm{C}$ ) and peroxidase conju- 
gated streptavidin (1:200 in the same buffer, $30 \mathrm{~min}$; reagents: Dako Corp., Glostrup, Denmark). Peroxidase activity was determined with diaminobenzidine enhanced with cobalt chloride $(1 \% \mathrm{w} / \mathrm{v}$, Sigma). Unlabelled nuclei were counterstained with calcium red, The sections were observed with a light microscope and for each sample the number of labelled nuclei was counted from a total area of $0.05 \mathrm{~cm}^{2}$ at 3 different locations.

Haematology and microbiology. The haematocrit was determined according to standard procedures (Houston 1990). To detect an infection of internal organs with bacteria, the carp were killed on the days stated above and material from dissected liver, spleen, and kidney was inoculated into sheep blood agar plates. The plates were incubated at room temperature (20 to $24^{\circ} \mathrm{C}$ ) for $48 \mathrm{~h}$ and then monitored for growth of bacteria colonies. Subcultures were made from each colony of a different morphological type. Material from the subcultures was used for bacteria identification according to standard procedures (Austin \& Austin 1993).

Statistics. The number BRDU-positive cells was evaluated in tissues of infected and uninfected carp, and differences between the groups were tested for significance $(p \leq 0.05)$ by means of Student's t-test. Prevalence and intensity of bacterial infection of internal organs was compared with a chi-square test.

\section{RESULTS}

\section{Parasite development, clinical signs and gross lesions}

All carp infected with Trypanoplasma borreli developed a parasitaemia. Trypanoplasms were first detected in blood samples taken at Day 14 PI, then the number of $T$. borreli increased rapidly until the end of the experiment at Day 28 PI (Fig. 1). Signs of disease were observed beginning with Day 18 PI. The carp had an enlarged marmorized spleen, pale gills and marked anaemia (Figs. $2 \& 3$ ). They reduced their food intake and their swimming and escape behavior. At Day $20 \mathrm{PI}$, a. swelling of the kidney and petechial haemorrhages in the kidney occurred; at Day 22 PI, haemorrhages were seen in the liver With a further increase in parasitaemia, at Day 24 PI, exophthalmia and an extension of the abdomen were observed. Mortalities occurred at Days 26 to 28. Moribund carp floated C-like at the water surface and died within a few hours.

Microbiological samples revealed, that 7 out of 18 Trypanoplasma borreli-infected carp harboured low numbers of Aeromonas spp. and Vibrio spp. in internal organs. Uninfected carp had an infection prevalence of 9 out of 18 carp. From the organs of 4 out of 36 carp examined, low numbers of non fluorescent Pseudo-

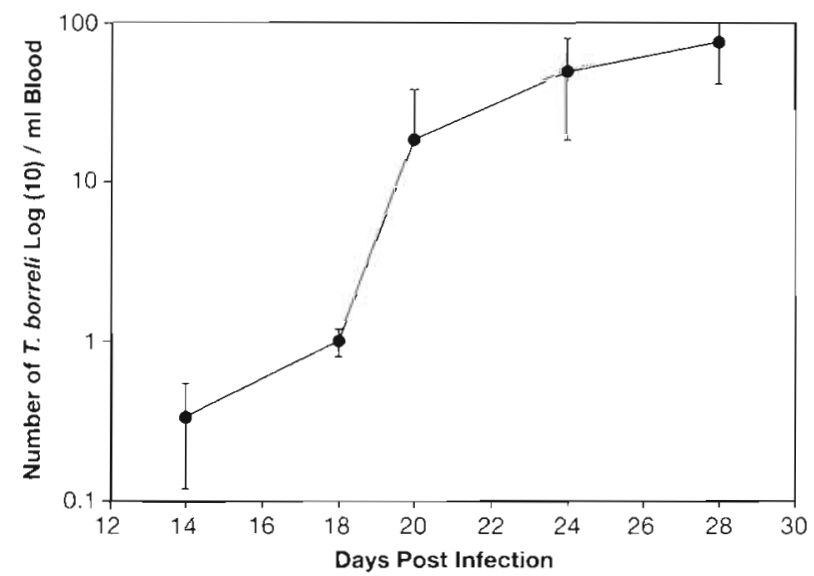

Fig. 1. Trypanoplasma borreli infecting Cyprinus carpio. Parasitemia of cloned $T$. borreli in the blood of experimentally infected common carp. The carp were infected by injection of 5000 parasites into the dorsal muscle and kept at $20 \pm 2^{\circ} \mathrm{C}$

monas spp. were isolated. By means of a chi-square test, significant differences in bacterium prevalences were not found when $T$. borreli-infected carp were compared to uninfected carp

\section{Histopathology}

Most prominent changes were observed in the kidney and spleen of infected carp. On kidney sections taken at the beginning of the parasitaemia, at Days 7 and 14 PI, lymphoid cells prevailed in glomerular capillaries and an increase of interstitial lymphoid tissue was observed when infected carp were compared to uninfected controls (Figs. 4 \& 5). In some tissue areas epithelium cells of renal tubules showed signs of dete-

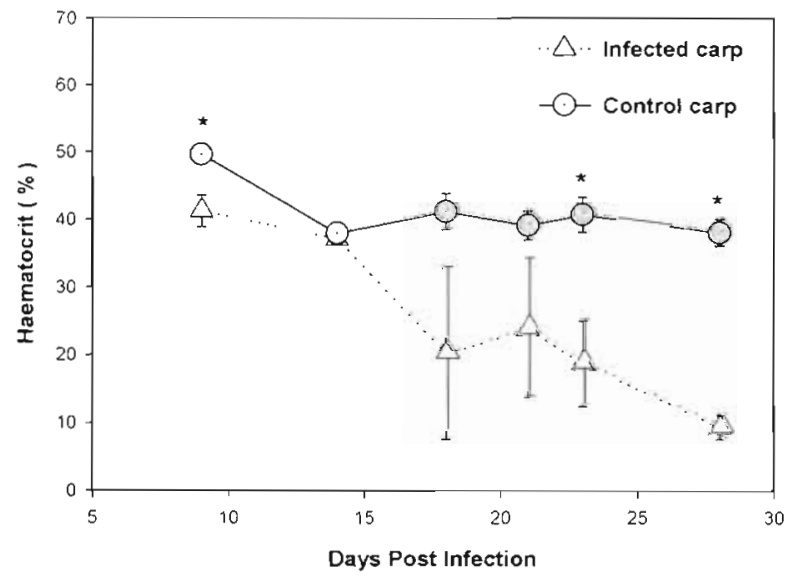

Fig. 2. Trypanoplasma borreli infecting Cyprinus carpio. Haematocrit values of the blood of carp infected with $T$ borreli. Shown are mean \pm standard deviation of haematocrit values of 5 carp each. ${ }^{*}$ Differences between controls and infected carp were statistically significant at $p \leq 0.01$ 


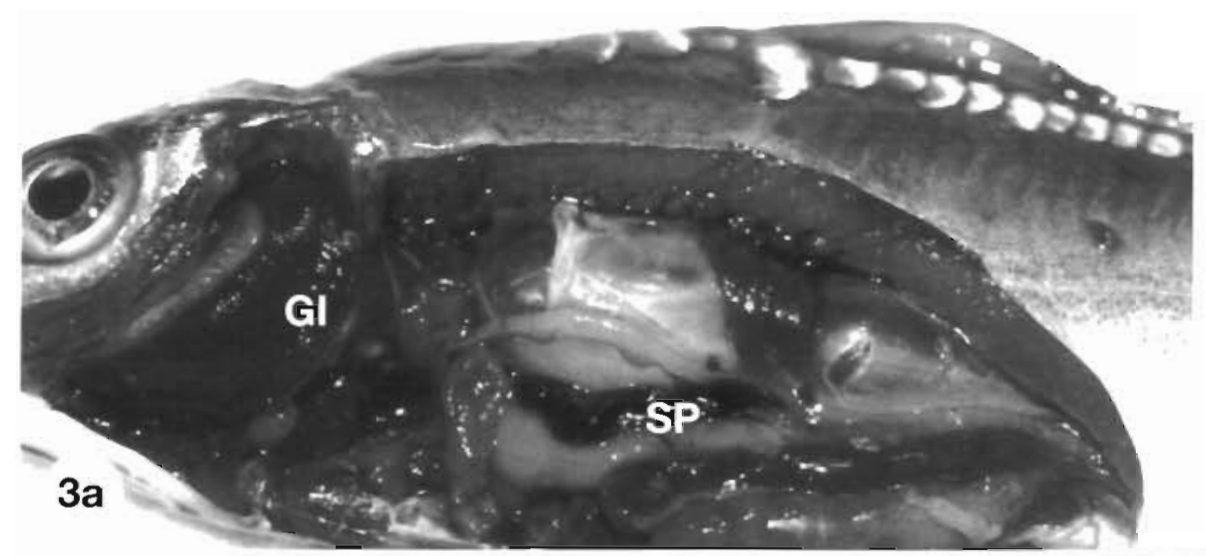

Fig. 3. Trypanoplasma borreli infecting Cyprinus carpio. Internal organs from (a) an unifected control carp and (b) a Trypanoplasma borreli-infected carp at Day 19 PI. The infected carp shows pale gills (G1), splenomegaly (SP) and swelling of the kidney

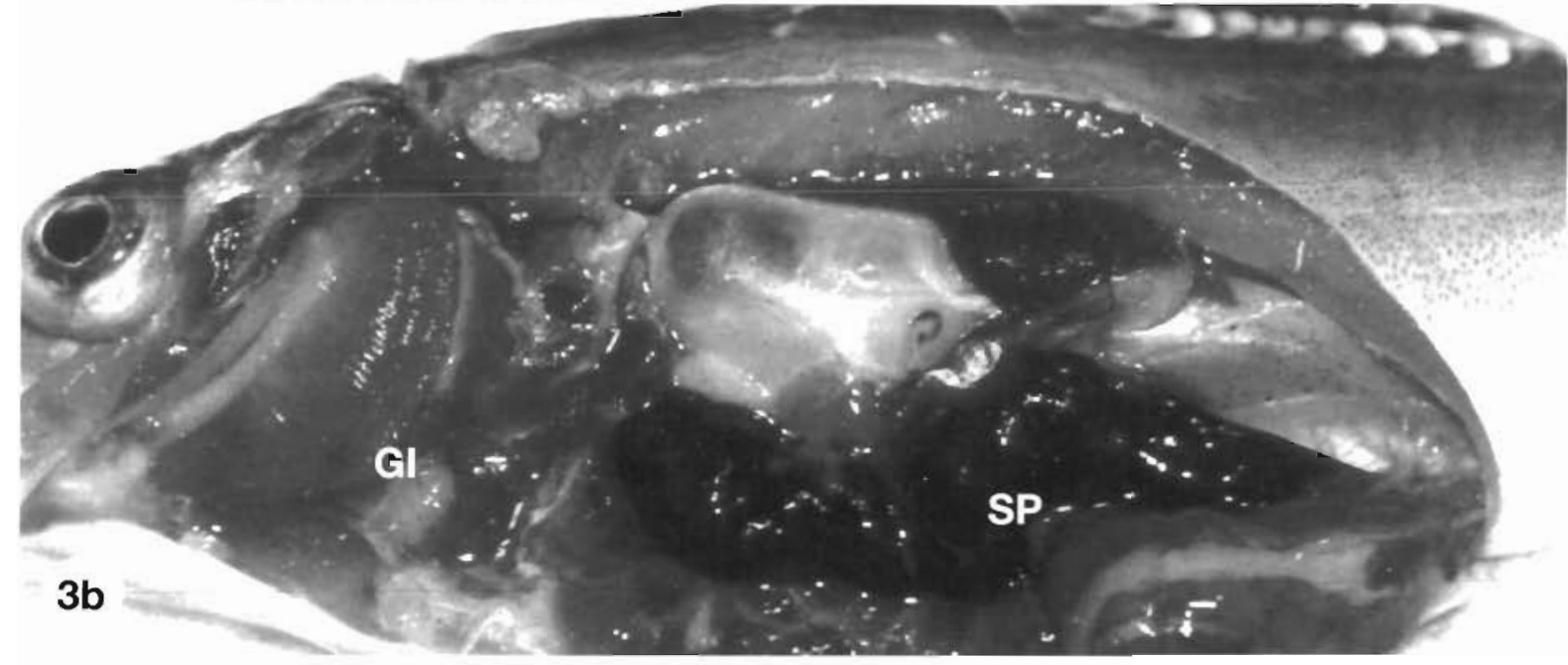

rioration: a cell oedema was formed and dilated tubuli were seen (Fig. 6). With increasing numbers of $T_{T Y}$ panoplasma borreli in the circulating blood, the accumulation of leukocytes in glomerular capillaries was more prominent and Bowman's space was reduced completely (Fig. 6). The proliferation of the interstitial lymphoid tissue had progressed further and numerous dividing cells and phagocytes with incorporated cellular debris were detected in the samples. The massive proliferation of lymphoid cells caused a severe deterioration of nephric tubules. The tubulus epithelium cells showed a progressive degeneration and finally atrophied (Figs. 7 \& 8). Additionally, massive accumulations of $T$. borreli were observed in blood vessels and in the interstitium of the kidney.

The induction of cell proliferation in renal interstitial tissue coinciding with the development of the parasitaemia was observed by BRDU incorporation as well. In uninfected carp, proliferating cells were found in the renal interstitium at a low level (Fig. 9). At the beginning of the parasitaemia, at Days 7 and 14 PI, BRDUpositive cells were present in increased numbers at the same locations. With increasing Trypanoplasma bor- reli numbers, at Days 18 to 20, the renal interstitium contained masses of proliferating cells (Figs. $10 \& 11$ ).

In the spleen, an activation of the white pulp with increasing cell proliferation was observed during the initial phase of the parasitaemia at Days 7 and 14 PI (Fig. 12). At Day 21 PI, when high numbers of Trypanoplasma borreli were present in the circulating blood, the spleen of some fishes showed haemorrhages with extensive accumulations of erythrocytes and $T$. borreli and a large number of proliferating lymphoid cells (Figs. $12 \& 13$ ). In other fishes, a marked elimination of erythrocytes, numerous granulocytes and focal accumulations of macrophages were seen. In all cases high numbers of proliferating cells were distributed in the tissue in a diffuse manner and did not form clusters or follicles (Fig. 14).

In the liver, a congestion of liver sinusoids and focal necroses of hepatic tissue were obsevered with the development of the parasitaemia (Fig. 15). In carp with high numbers of Trypanoplasma borreli in the circulating blood, capillaries from gills, heart, intestine and brain were filled with masses of trypanoplasms and lymphoid cells (Fig. 16). 

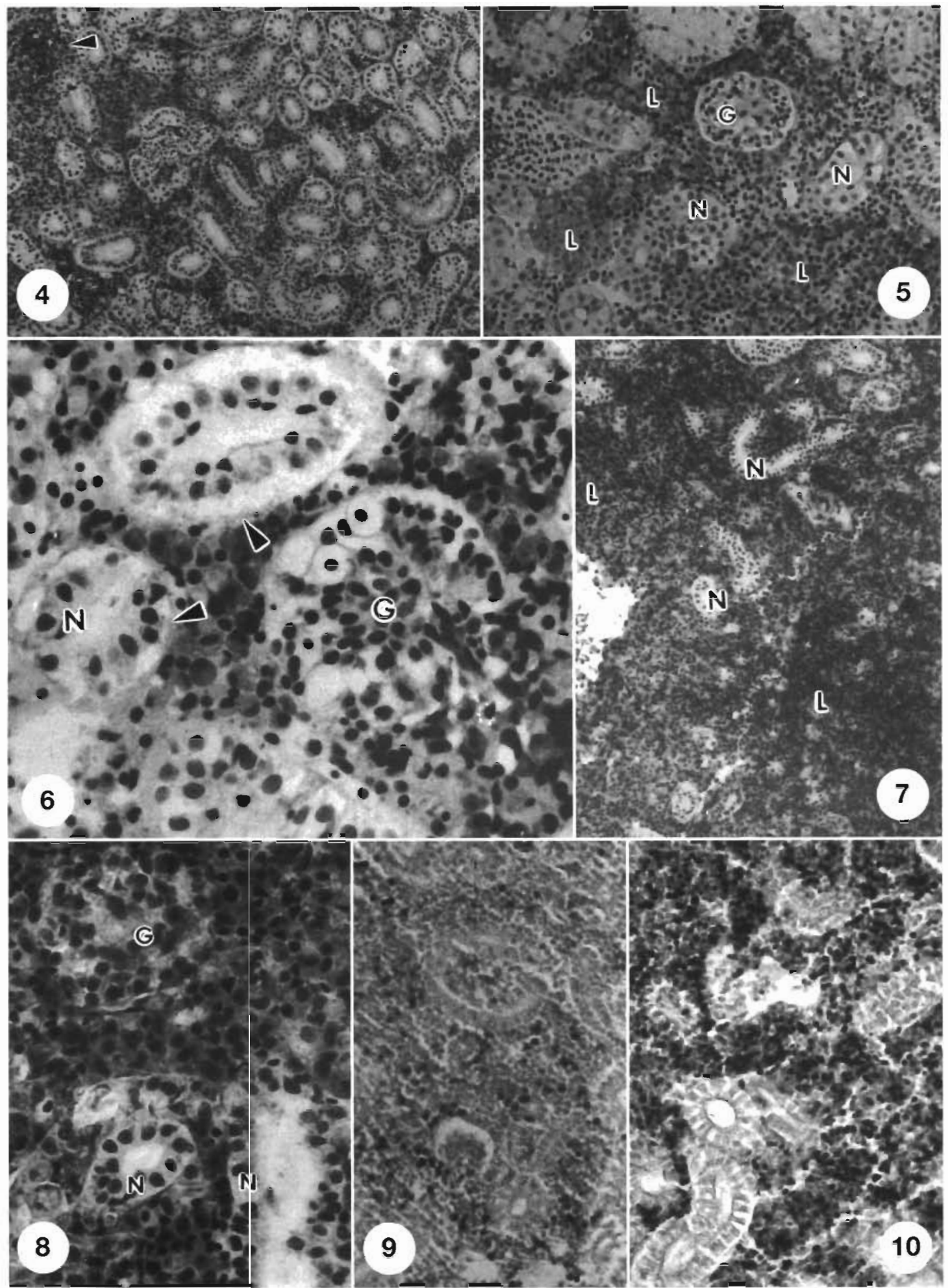

Figs. 4 to 10. Trypanoplasma borreli infecting Cyprinus carpio. Histology of the kidney of uninfected carp and carp infected with T. borreli. Fig. 4. On kidney sections of uninfected carp renal corpuscles (arrowhead) and cross sections of tubuli are embedded in lymphoid interstitial tissue. Fig. 5. Kidney of $T$. borreli-infected carp $7 \mathrm{~d}$ PI. An activation of interstitial lymphoid tissue (L) can be observed. G: glomerulum, $\overline{\mathrm{N}}$ : nephric tubules. Fig. 6. T. borreli infection, $7 \mathrm{~d}$ PI: accumulations of lymphocytes were seen in glomerular capillaries $(\mathrm{G}$ ) and a cell oedema in epithelium cells of renal tubules ( $\mathrm{N}$, arrowheads) was formed. Fig. 7 . Overview of the kidney from a $T$. borreli-infected carp at $19 \mathrm{~d}$ PI with marked accumulations of lymphoid cells (L) and extensive deterioration of nephric tubules (N). Fig. 8. Degeneration of nephric tubules (N) in the kidney of $T$. borreli-infected carp at 19 d PI. Figs. 9 \& 10. Envisualization of proliferating leukocytes in the kidney of carp by BRDU labelling. Fig. 9. Uninfected control carp. Fig. 10. Kidney section of a T. borreli-infected carp at $19 \mathrm{~d}$ PI 


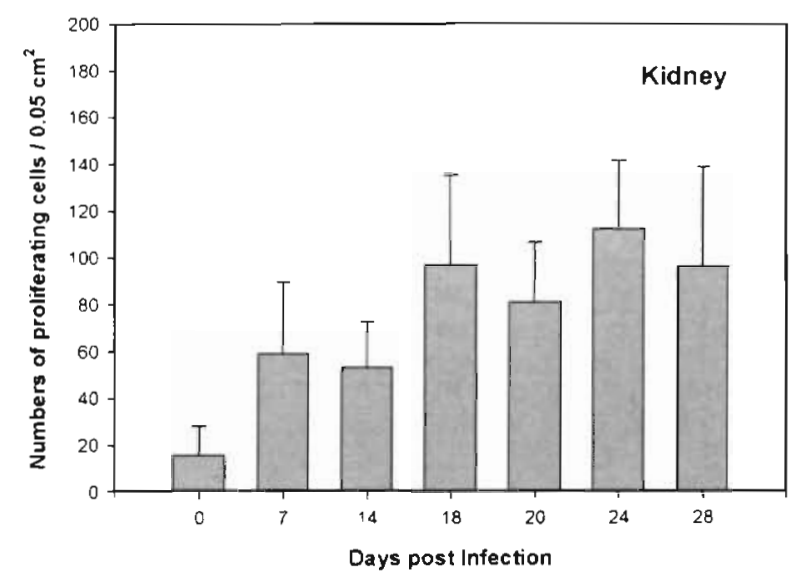

Fig. 11. Trypanoplasma borreli infecting Cyprinus carpio. Proliferating cells in the kidney of common carp infected with $T$. borreli. Shown are mean and standard deviation of BRDUpositive cells in kidney sections of 3 individual carp

\section{DISCUSSION}

Carp from the inbred line used in our study were found to be very susceptible to infections with Trypanoplasma borreli. All fish injected with the parasite developed signs of disease and subsequently died. Fatal infections of carp or tench were observed in aquaculture ponds mainly in association with hibernation or with other diseases (Schäperclaus 1979, Amlacher 1992, Lom \& Dykova 1992), while laboratory infections of goldfish or juvenile carp frequently resulted in high mortalities (Lom \& Dykova 1992, Wiegertjes et al. 1995). In carp the susceptibility to disease was found to depend on host genetics or on the parasite strain (Wiegertjes et al. 1995). The number of inoculated parasites, temperature, or body size of the fish were less important for mortality rates (Steinhagen et al. 1989, Jones et al. 1993).

In all cases, susceptible fish developed progressive anaemia, pale gills, exophthalmia, abdominal distension and, in the final stage of disease, a lethargic condition with loss of normal reactions ('sleeping sickness of carp'; Lom \& Dykova 1992). These clinical signs of trypanoplasmosis were also observed in the carp used in the present study.

Clinical changes associated with trypanoplasmosis or with trypanosome infections in fish are haematological changes such as decrease of haematocrit, erythrocyte number, serum protein content and serum osmolarity (Lom \& Dykova 1992, Woo \& Poynton 1995). Cryptobia salmositica, a Trypanoplasma-related flagellate from the blood circulation of North American salmonids, was observed to cause an anaemia, which was directly related to the parasitaemia (Woo 1979). Because $C$. salmositica secretes haemolysins which directly lyse red blood cells, Woo \& Poynton (1995) argued that the anaemia was induced by the parasite. In our experiments, the anaemia increased with increasing numbers of blood flagellates and large numbers of damaged (?) erythrocytes aggregated in the spleen of infected carp. Whether $T$. borreli also secretes enzymes which lyse red blood cells remains to be investigated. In many fishes, the spleen acts as a storage reservoir for erythrocytes, and under appropriate conditions, including hypoxia or exercise, the spleen can liberate the sequestered red blood cells into the circulation and thus elevate the blood oxygen carrying capacity (Perry \& McDonald 1993). The oxygen solubility of fish plasma is very low and is assumed to contribute only about $5 \%$ to the total oxygen carrying capacity of the blood (Perry \& McDonald 1993). There is some evidence that in carp and salmonids this might suffice for resting metabolism (Bone et al. 1995), but when exercise or disease conditions increase the oxygen demand of the fish, it is then likely to suffer from hypoxia. Therefore, anaemic fish are at risk of hypoxia, because the oxygen uptake at the gills is reduced due to a lack in oxygen transporting red blood cells (Roberts 1989).

The most prominent histopathologcal effects associated with a Trypanoplasma infection were focal haemorrhages, congestion of blood vessels and, in severe parasitaemias occlusion of capillaries by parasites or inflammatory cells. These reactions were observed in salmonids infected with Cryptobia salmositica (Woo \& Poynton 1995), goldfish with a T. borreli infection (Dykova \& Lom 1979, Lom et al. 1986) and in the present study. In goldfish infected with $T$. borreli, kidney, spleen, liver, and fat tissue were found to be affected. In the blood vessels supplying all internal organs, an endovasculitis with a marked endothelial hyperplasia was seen (Dykova \& Lom 1979). In our study, glomerular capillaries of the kidney, hepatic sinusoids, and blood vessels from organs such as heart and intestine were infiltrated by inflammatory cells and trypanoplasms. These can be considered to increase the severity of the anaemia and to cause a serious disturbance of blood circulation.

In addition to the vascular changes a generalized inflammatory reaction was seen in fish with acute haemoflagellate infections (Lom \& Dykova 1992, Woo \& Poynton 1995). Trypanoplasma borreli-infected carp and goldfish (Lom et al. 1986, Lom \& Dykova 1992, present study) as well as Cryptobia salmositicainfected salmonids (Woo \& Poynton 1995) developed a marked lymphocytosis. In liver, gills and spleen of juvenile rainbow trout infected with $C$. salmositica, endovasculitis and a mononuclear infiltration occurred with increasing parasite numbers (Woo \& Poynton 1995). In the kidney of $T$. borreli infected goldfish in- 


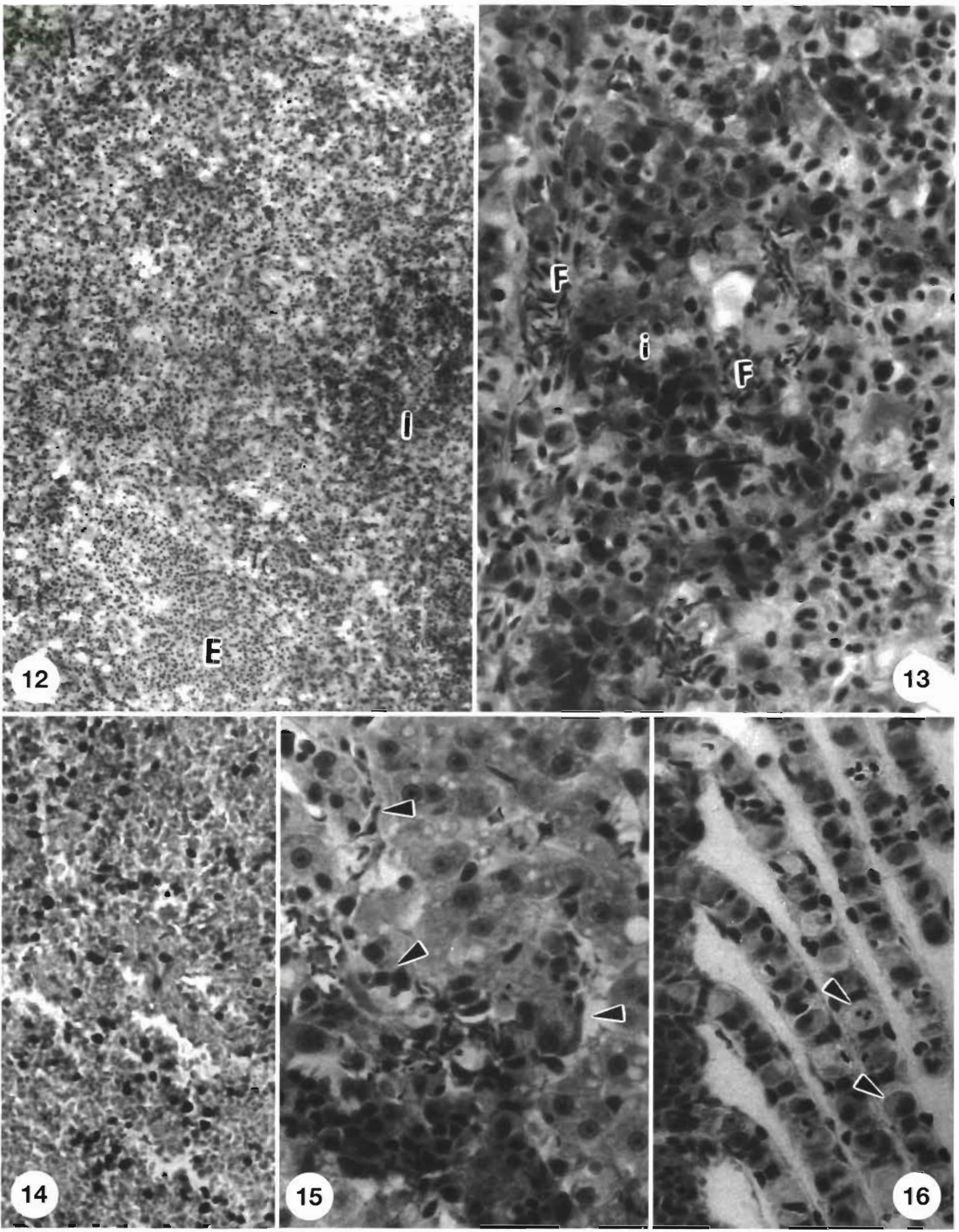

Figs. 12 to 16. Trypanoplasma borreli infecting Cyprinus carpio. Histology of spleen, liver and gills of carp infected with T. borreli Fig. 12. In the spleen, accumulations of erythrocytes $(E)$ and inflammatory cells (I) were seen. Fig. 13. Spleenic sinusoids are congested by trypanoplasms (F) and accumulations of inflammatory cells (i). Fig. 14. Numerous proliferating cells (black), visualized by BRDU labelling, are scattered in the spleen of $T$. borreli-infected carp. Fig. 15 . In the liver of $T$ borreli-infected carp, sinosoids are congested by masses of flagellates and inflammatory cells (arrowheads). Fig. 16. The sinusiods of the secondary lamellae of gills from $T$ borreli-infected carp are filled with masses of inflammatory cells (arrowheads) 
tracapillary glomerulitis and tubulonephrosis was observed (Dykova \& Lom 1979). Similar lesions were found in the present study while observing a $T$. borreli infection in common carp. The most prominent reaction was a severe proliferation of mononucleic cells from the interstitial lymphoid tissues in the kidney. This proliferation was already induced by Day 7 PI as could be seen in BRDU-labelled preparations (present study) and by flow cytometric analysis (BarckhausenKiesecker 1996, Hamers \& Goerlich 1996). With further development of the parasitaemia, this proliferation progressed extensively and caused a severe depression of the nephric tubules.

The interstitial haematopoietic tissue of the kidney of teleosts bears a close resemblance to the bone marrow of higher vertebrates but differs in having a highly active reticuloendothelial and antibody-producing cell component (Ellis 1989, Zapata \& Cooper 1990, Manning 1994). In the kidney and in the spleen of teleost fishes, cells of the interstitial haematopoietic tissue respond to the antigenic stimulation by proliferation, as in lymphoid organs of higher vertebrates. Proliferating cells were found to be scattered in a diffuse pattern throughout the kidney and the spleen rather than forming follicles or germinal centres as found in mammalian lymph nodes (Manning 1994). The intensive proliferation of mononuclear cells, which took place in the kidney and spleen of Trypanoplasma borreli-infected carp, therefore, can be considered a normal immune reaction of the fish directed against the parasite infection. In the kidney, an immediate proliferation response to the parasite infection was observed. It continued up to Day 28 PI, when mortalities occurred among infected fish, and it was found to induce pressure atrophies of the excretory tissue. In the spleen, an initial proliferation of inflammatory cells was observed. It peaked at Days 18 and 20 PI. In moribund fishes sampled at later dates trypanoplasms had infiltrated the spleenic tissues and extensive accumulations of erythrocytes were observed and formed haemorrhagic foci.

The histopathological changes in the kidney of carp infected with Trypanoplasma borreli were similar to the alterations in salmonids suffering from proliferative kidney disease. In the kidney of these fish a haematopoietic hyperplasia, vascular pathology and diffuse inflammatory changes were observed (Körting \& Schlotfeldt 1981, Kent \& Hedrick 1986, Clifton-Hadley et al. 1987, Körting et al. 1989). The vascular changes included occlusion of blood vessels in several organs, apparent haemoglobin crystallization, and destruction of renal excretory structures due to a massive proliferation of the renal interstitial lymphoid tissue. The most frequent clinical signs were abdominal distension and exophthalmia (Kent \& Hedrick 1986, Clifton-Hadley \& Richards 1987).
The glomerulitis and tubulonephritis induced by an extensive proliferation of the interstitial renal tissue is thought to impair the osmoregulatory function of the kidney, which in addition to the anaemia may be considered a major cause of disease. Freshwater teleosts have to meet a constant influx of water into body tissues along an osmotic gradient. To maintain ionic and water balance, excess of water has to be excreted by renal structures (Evans 1993). In freshwater fish damage to renal tissue is often associated with osmotic challenge and an accumulation of ascitic fluid. This occurs, for instance, in Hoferellus carassii infections of goldfish (Lom \& Dykova 1992), tuberculosis in ornamental fishes (Roberts 1989), and Cryptobia salmositica in rainbow trout (Woo 1979). Abdominal distension due to accumulation of ascitic fluid also was observed in moribund Trypanoplasma borreli-infected carp in the present study.

Our study indicates that the pathogenicity of Trypanoplasma borreli to susceptible carp and goldfish can be related to a hypoxia caused by a severe anaemia and to the impairment of the osmoregulatory function of the kidney. An osmotic challenge of parasitized carp must be concluded from the deterioration of renal excretory structures which is mainly caused by a massive proliferation of interstitial mononuclear cells. To answer questions relating to immunological mechanisms behind the observed pathology, it would be rewarding to study the activation characteristics of renal interstitial cells in response to antigen challenge.

Acknowledgements. S.B. was supported by and is grateful for a grant from the Mahanakorn University of Technology, Bangkok, Thailand. S. H. Leenstra and Dr G. Wiegertjes, Wageningen Agricultural University, The Netherlands, kindly provided fertilized carp eggs.

\section{LITERATURE CITED}

Amlacher E (1992) Taschenbuch der Fischkrankheiten: Grundlagen der Fischpathologie, 6th edn. Gustav Fischer, Jena

Austin B, Austin DA (1993) Bacterial fish pathogens: disease in farmed and wild fish, 2nd edn. Ellis Horwood Ltd, Chichester

Barckhausen-Kiesecker I (1996) Untersuchung lymphoider Organe von Karpfen (Cyprinus carpio) im Verlauf parasitärer Infektionen. PhD thesis, Vet School, Hannover

Bone Q, Marshall NB, Blaxter JHS (1995) Biology of fishes. Blackie Academic \& Professional, London

Clifton-Hadley RS, Bucke D, Richards RH (1987) A study of the sequential clinical and pathological changes during proliferative kidney disease in rainbow trout, Saimo gairdneri Richardson. J Fish Dis 10:335-352

Dykova I, Lom J (1979) Histopathological changes in Trypanosoma danilewskyi Laveran \& Mesnil, 1904 and Trypanoplasma borreli Laveran \& Mesnil, 1902 infections of goldfish, Carassius auratus (L.). J Fish Dis 2:381-390 
Ellis AE (1989) The immunology of teleosts. In: Roberts RJ (ed) Fish pathology. Baillière Tindall, London, p 135-154

Evans DH (1993) Osmotic and ionic regulation. In: Evans DH (ed) The physiology of fishes. CRC Press, Boca Raton, Florida, p 315-341

Hamers R, Goerlich R (1996) Flow cytometric DNA analysis of the haematopoietic tissue of carp Cyprinus carprio during experimental infection with the haemoflagellate Trypanoplasma borreli. Dis Aquat Org 24:129-134

Hemmer N, Steinhagen D (1995) ldentification of proliferating cells in piscine tissues by incorporation and immunocytochemical detection of bromodeoxy-uridine. Bull Eur Assoc Fish Pathol 15:165-167

Houston AH (1990) Blood and circulation. In: Schreck CB, Moyle PB (eds) Methods for fish biology. American Fisheries Society, Bethesda, MD, p 273-334

Jones SRM, Palmen M, van Muiswinkel WB (1993) Effects of inoculum route and dose on the immune response of common carp. Cyprinus carpio to the blood parasite, Trypanoplasma borreli. Vet Immunol Immunopathol 36:369-378

Kent ML, Hedrick RP (1986) Development of the PKX myxosporean in rainbow trout Salmo gairdneri. Dis Aquat Org $1: 169-182$

Keysselitz G (1906) Generations- und Wirtswechsel von Trypanoplasma borreli Laveran und Mesnil. Arch Protistenkd $8: 1-71$

Körting W, Schlotfeldt HJ (1981) Proliferative kidney disease (PKD) of rainbow trout in an intensive aquaculture unit of Northern Germany. In: Acuigrup (ed) Fish diseases. FAO/EIFAC COPRAQ-IV Meeting, Cádiz, p 1-6

Körting W, Lehmann J, Stürenberg FJ, Mock D (1989) Zur proliferativen Nierenerkrankung (proliferative kidney disease [PKD]) der Salmoniden. Tierärztl Prax 17:217-220

Kruse P, Steinhagen D, Körting W (1988) Morphological development of Trypanoplasma borreli Laveran \& Mesnil, 1901 (Mastigophora: Kinetoplastida) in Cyprinus carpio L. Verh Dtsch Zool Ges 81:274

Kruse P, Steinhagen D. Körting W (1989) Development of Trypanoplasma borreli (Mastigophora: Kinetoplastida) in the leech vector Pisicola geometra and its infectivity for the common carp, Cyprinus carpio. J Parasitol 75:527-530

Lom $J$ (1979) Biology of the trypanosomes and trypanoplasms of fish. In: Lumsden WHR, Evans DA (eds) Biology of the Kinetoplastida. Academic Press, London, p 269-337

Lom J, Dykova I (1992) Protozoan parasites of fishes. Developments in aquaculture and fisheries science, Vol 26 Elsevier, Amsterdam

Lom J, Dykova I, Machackova B (1986) Experimental evi-

Editonal responsibility: Otto Kinne (Managing Editor). Oldendorf/Luhe, Germany dence of pathogenicity of Trypanoplasma borreli and Trypanosoma danilewski for carp fingerling. Bull Eur Assoc Fish Pathol 6:87-88

Lukes J, Jirku M, Dolezel D, Kralova I, Hollar L, Maslov DA (1997) Analysis of ribosomal RNA genes suggests that trypanosomes are monophyletic. J Mol Evol 44:521-527

Manning MJ (1994) Fishes. In: Turner RJ (ed) Immunologya comparative approach. Wiley, Chichester, p 69-100

Perry ST, McDonald G (1993) Gas exchange. In: Evans DH (ed) The physiology of fishes. CRC Press, Boca Raton, FL, p 251-278

Roberts RJ (1989) Fish pathology, 2nd edn. Bailliére Tindall, London

Robertson M (1912) Transmission of flagellates living in blood of certain freshwater fishes. Phil Trans R Soc Lond 202 $29-48$

Romeis B (1989) Mikroskopische Technik, 17th edn. Urban \& Schwarzenberg, München

Schäperclaus W (1979) Fischkrankheiten. VEB AkademieVerlag, Berlin

Schutte B, Reynders MM, Reynders FT, Bosman FT, Blijham GH (1987) Studies with anti-bromodeoxyuridine antibodies: II. Simultaneous immunocytochemical detection of antigen expression and DNA synthesis by in vivo labeling of mouse intestinal mucosa. J Histochem Cytochem 35: $371-374$

Steinhagen D, Kruse P, Körting W (1989) The parasitemia of cloned Trypanoplasma borreli Laveran and Mesnil, 1901 in laboratory-infected common carp (Cyprinus carpio). J Parasitol 75:685-689

Wiegertjes GF, Groeneveld A, van Muiswinkel WB (1995) Genetic variation in susceptibility to Trypanoplasma borreli infection in common carp (Cyprinus carpio L.). Vet Immunol Immunopathol 47:153-161

Wiemer EAC, Hannaert V, van den Ijssel PRLA, van Roy J, Opperdoes FR, Michels PAM (1995) Molecular analysis of glyceraldehyde-3-phosphate dehydrogenase in Trypanoplasma borelli: an evolutionary scenario of subcellular compartmentation in kinetoplastida. J Mol Evol 40:443-454

Woo PTK (1979) Trypanoplasma salmositica: experimental infections in rainbow trout, Salmo gairdneri. Exp Parasitol 47:36-48

Woo PTK, Poynton SL (1995) Diplomonadida, kinetoplastida and amoebida (Phylum Sarcomastigophora). In: Woo PTK (ed) Fish diseases and disorders. CAB International, Wallingford, p 27-96

Zapata AG, Cooper EL (1990) The immune system: comparative histophysiology. Wiley, Chichester

Submitted: May 6, 1999; Accepted: November 16, 1999

Proofs received from author(s): January 24, 2000 